\title{
Tantangan dan Peluang Penyuluh Agama di Era Digital
}

\author{
Abdul Rahman \\ UIN Syarif Hidayatullah Jakarta \\ abdulr@gmail.com
}

\begin{abstract}
In the midst of the COVID-19 pandemic, every policymaker in this country needs to be serious in overcoming the outbreak and continuing to carry out development. The main goal of development is human development, because without human change there is basically no development. Changes in human self can be expected, among others, due to extension activities, which lead to changes in knowledge, skills, and attitudes. One of the extensions is the process of changing behavior with a communication approach. So that religious instructors master communication both in theory and in practice. Communication skills are a basic competency as a professional religious educator in the digital era.
\end{abstract}

Keywords: religious instructor, communication, digital era

\begin{abstract}
Abstrak
Di tengah pandemi covid 19 diperlukan keseriusan setiap pemangku kebijakan di negara ini dalam mengatasi wabah dan terus melakukan pembangunan. Sasaran utama pembangunan adalah pembangunan manusia, karena tanpa ada perubahan manusia pada dasarnya tidak ada pembangunan. Perubahan diri manusia dapat diharapkan antara lain karena adanya kegiatan penyuluhan, yang menimbulkan perubahan pengetahuan, ketrampilan, serta sikap. Penyuluhan salah satunya merupakan proses pengubahan perilaku dengan pendekatan komunikasi. Sehingga penyuluh agama menguasai komunikasi baik secara teori maupun secara praktiknya. Kemampuan komunikasi merupakan kompetesi dasar sebagai penyuluh agama yang profesional di era digital.

Kata kunci : penyuluh agama, komunikasi, era digital

Permalink/DOI: http://doi.org/10.15408/dakwah.v25i1.23185
\end{abstract}




\section{Pendahuluan}

Penyuluhan bukanlah monopoli bidang pertanian saja, melainkan penyuluhan ini telah dipergunakan secara meluas mencakup seluruh aspek pembangunan nasional di Indonesia, diantaranyaadalah pembangunan di bidang keagamaandankesejahteraan sosial. Perubahan-perubahan yang terjadi pada penduduk suatu bangsa diharapkan dapat terjadi secara terus menerus. Pencapaian pembangunan secara fisik dan ekonomi akan kurang memberikan arti jika tidak disertai dengan pembangunan manusianya, karena pencapaian pembangunan tersebut merupakan hasil dari pembangunan manusia seutuhnya.

Sasaran utama pembangunan adalah pembangunan manusia, karena tanpa adanya perubahan yang terjadi di dalam diri manusia yang dibangun, maka akan sulit untuk mencapai perbaikanperbaikan secara terus menerus, sehingga hasil pembangunan fisik ekonomi menjadi kurang berarti jika tidak dibarengi dengan keberhasilan pembangunan manusianya. Perubahan pada diri manusia yang diharapkan dapat terjadi karena adanya kegiatan penyuluhan, yaitu adanya perubahan akan pengetahuan, ketrampilan, serta sikapnya. Dalam pelaksanaan kegiatan penyuluhan agama, sasaran yang ingin dicapai juga berupa peningkatan pengetahuan, ketrampilan dan sikap dari kelompok sasaran.

Untuk mencapai kemajuan tersebut di atas, maka dalam diri seseorang harus terdapat kemauan untuk melakukan perubahan dengan tindakan nyata yang sistimatis, bertahap dan berkesinambungan. Penyuluhan merupakan jembatan penghubung kesenjangan antara sumber pengetahuan /pembaharu atau change agentdengan sumber permasalahan, sehingga terjadi adanya perubahan pada kelompok sasaran. Penyuluhan dalam arti umum adalah ilmu sosial yang mempelajari sistem dan proses perubahan pada individu serta masyarakat agar dapat terwujud perubahan yang lebih baik sesuai dengan yang diharapkan. Penyuluhan, dengan demikian dapat diartikan sebagai suatu sistem pendidikan yang bersifat nonformal di luar sistem sekolah yang biasa, sehingga terjadi adanya peningkatan pengetahuan, ketrampi;an, dan sikap mentalnya menjadi lebih baik; dan pada akhirnya kelompok sasaran sejahtera dan bermartabat.

Istilah penyuluhan yang sebenarnya berasal dari kata extension, yang diartikan sebagai perluasan atau penyebarluasan. Sehingga Mardikanto (1991) seorang ilmuwan pertanian mengartikan penyuluhan adalah: proses penyebarluasan informasi atau proses memberikan penerangan kepada masyarakat tentang segala sesuatu yang belum diketahui sehingga dapat dilaksanakan/ditrapkan. Proses penyebaran informasi di dalam penyuluhan sebenarnya tidaklah sekedar penyampaian informasi, akan tetapi terkandung maksud yang lebih jauh, yakni: untuk difahami, dikaji, dianalisis, dan diterapkan/dilaksanakan oleh 
kelompok sasaran. Memberikan penerangan secara terus menerus sampai diyakini bahwa informasi tersebut benarbenar telah difahami, dihayati, dan dilaksanakan oleh kelompok sasaran. Penyuluh tidak boleh merasa jenuh untuk melaksanakan tugas penyuluhan tentang hal yang sama.

Selain dari istilah extension juga secara harfiah, penyuluhan bersumber dari kata suluh yang bearti obor atau suatu alat untuk menerangi keadaan yang gelap. Dari asal perkataan tersebut dapat diartikan bahwa penyuluhan dimaksud untuk memberi penerangan ataupun penjelasan kepada mereka yang disuluhi, agar tidak lagi berada dalam kegelapan mengenai sesuatu/masalah tertentu. Penyuluhan memang diartikan bermacam-macam, Claar et al (Zulkarimein, 1989) mengakui hal tersebut karena penyuluhan diartikan sebagai kegiatan untuk memperluas (extending) berbagai pelayanan kepada para kelompok masyarakat. Sehingga Claar (1989) membuat rumusan bahwa penyuluhan merupakan pendidikan khusus pemecahan masalah yang berorientasi pada tindakan, yang mengajarkan sesuatu, mendemonstrasikan, dan memotivasi, tapi tidak melakukan pengaturan (regulating) dan tidak melaksanakan program yang non-edukatif.

Pendapat ahli penyuluhan pembangunan Margono Slamat (Totok Mardikanto, 1991) bahwa penyuluhan adalah "proses perubahan perilaku (pengetahuan, sikap, dan ketrampilan) di kalangan masyarakat agar mereka tahu, mau dan mampu melaksanakan perubahan dalam usahanya, demi tercapainya peningkatan produktifitas dan perbaikan kesejahteraan keluarga/masyarakat melalui pembangunan”. Tentang perubahan perilaku tersebut, sebenarnya dapat dilakukan dengan berbagai cara, seperti melalui: pembujukan, pemberian stimulan/intensif atau bantuan, pendidikan, atau ada sedikit pemaksaan. Dalam hal ini penyuluhan sebenarnya merupakan proses perubahan perilaku dengan melalui pendekatan pendidikan, yang dilatarbelakangi oleh:

a. Pengetahuan/pemahaman tentang segala sesuatu yang dinilainya lebih baik atau bermanfaat bagi klompok sasaran, keluarganya, dan masyarakatnya.

b. Dengan kemauan sendiri tanpa paksaan dari pihak manapun juga.

c. Kemampuan untuk melakukan sesuatu dan menggunakan sumberdaya yang diperlukan sehingga terjadi perubahan.

Sehingga penyuluhan dengan pendekatan pendidikan, sering berlangsung sangat lambat, melelahkan, dan memerlukan kesabaran, biaya dan waktu yang lebih besar. Berbeda dengan penyuluhan dengan pemaksaan, yang biasanya perubahan itu berlansung cepat, akan tetapi cepat juga kembali pada perilaku semula jika pemaksaan menurun. Perubahan yang dibentuk dari proses penyuluhan akan bersifat kekal seumur hidup, bahkan sering kali dapat mendorong terjadinya perubahan- 
perubahan lainatas kemauan sendiri (Mardikanto, 1991).

Begitu juga Samsudin (1977) menyatakan tentang penyuluhan adalah sistem pendidikan non formal tanpa paksaan menjadikan seseorang sadar dan yakin bahwa sesuatu yang dianjurkan akan membawa ke arah perbaikan dari hal-hal yang dikerjakan sebelumnya. Dari rumusan tersebut dapat diambil tiga hal yang sangat penting, yaitu: "sistem pendidikan non formal", "mengajak orang sadar", dan "menyampaikan sesuatu yang baru". Ketiga hal tersebut memang senantiasa melekat dalam setiap kegiatan penyuluhan, karena penyuluhan pada hakekatnya merupakan suatu langkah dalam usaha mengubah suatu masyarakat menuju keadaan yang lebih baik seperti yang diharapkannya. Penyuluhan merupakan suatu usaha menyebarluaskan hal-hal yang baru agar masyakat mau tertarik dan berminat untuk melaksanakannya dalam kehidupan mereka sehari-hari. Penyuluhan juga merupakan suatu kegiatan mendidikan sesuatu kepada masyarakat, memberi mereka pengetahuan, informasi-informsi, dan kemampuan-kemampuan baru, agar mereka dapat membentuk sikap dan berperilaku hidup menurut apa yang seharusnya.

Elsey dan Hearne (1955) menyatakan bahwa penyuluhan harus berpijak kepada pentingnya pengembangan individu di dalam perjalanan pertumbuhan masyarakat dan bangsanya, sehingga falsafahnya penyuluhan adalah bekerja bersama masyarakat, untuk membantunya agar mereka dapat meningkatkan harkatnya sebagai manusia. Dari falsafah tersebut bila ditelusuri terkandung: (1) penyuluh harus bekerjasama dengan masyarakat, mampu menciptakan suasana dialogis, mampu menumbuhkan, menggerakkan serta memelihara partisipasi masyarakat; (2) penyuluhan tidak menciptakan ketergantungan, akan tetapi harus mampu mendorong semakin terciptanya kreativitas dan kemandirian kelompok sasaran, agar memiliki kemampuan untuk berswakarsa, swadaya, swadana, dan swakelola; (3) penyuluhan yang dilaksanakan, harus selalu mengacu kepada terwujudnya kesejahteraan dan peningkatan harkat martabat sebagai manusia.

Sebagai kenyataan yang tidak dapat dipungkiri adalah "kegiatan penyuluhan" bukan lagi kegiatan sukarela, akan tetapi telah berkembang menjadi suatu "profesi". Oleh karena itu setiap penyuluh perlu memegang teguh "Etika Penyuluhan". Etika bukanlah peraturan, akan tetapi lebih dekat kepada nilai-nilai moral untuk membangkitkan kesadaran untuk beraktifitas baik, dan jika dilupakan atau dilanggar akan berakibat tercemarnya pribadi yang bersangkutan. Hal tersebut di atas, Salmon Padmanegara seorang ahli penyuluhan pertanian (1987) menyatakan ada beberapa perilaku yang harus ditunjukkan oleh seorang penyuluh, antara lain:

a. Perilaku sebagai manusia seutuhnya, yaitu manusia yang 
beriman pada Tuhan YME, jujur dan disiplin.

b. Perilaku sebagai anggota masyarkat, yaitu mau menghormati adat/kebiasaan masyarakatnya, menghormati kelompok sasaran dan keluarganya, dan menghormati sesama penyuluh.

c. Perilaku sebagai penyuluh yang handal, yaitu berkeyakinan kuat atas manfaat tugasnya, memiliki tanggungjawab yang besar untuk melaksanakan pekerjaannya, memiliki jiwa kerjasama yang tinggi, dan berkemampuan untuk bekerja secara teratur.

d. Perilaku yang mencerminkan dinamika, yaitu penyuluh harus ulet, daya mental juang dan semangat kerja yang tinggi, selalu berorientasi mencerdaskan diri dan meningkatkan kemampuannya.

Dari semua pandangan dan pendapattentang penyuluhan, yang memaknai sebagai bentuk kegiatan penyebarluasan informasi, sebagai bentuk kegiatan pengubahan perilaku, sebagai bentuk kegiatan pendidikan nonformal tanpa pemaksaan, sebagai bentuk kegiatan memperluas pelayanan, sebagai bentuk kegiatan untuk menerangi suatu kegelapan atau ketidaktahuan, dan banyak lagi pandangan tentang hal tersebut; maka rumusan kegiatan penyuluhan khusus di bidang keagamaan tentu mempunyai nomenklatur tersendiri. Berdasarkan Peraturan
Menteri PAN-RB No. 9 Tahun 2021 Tentang Penyuluh Agama, bahwa rumusan penyuluhan agama adalah:

Suatu proses pengubahan perilaku yang dilakukan melalui penyebarluasan informasi, komunikasi, motivasi, konseling, edukasi, fasilitasi dan advokasibaik secara lisan, tulisan dan praktik dalam rangka pengembangan pengetahuan, sikap dan perilaku kelompok sasaran agar mereka mengetahui, termotivasi dan mampu memahami, melaksanakan ajaran agama dengan benar sekaligus mempunyai kepedulian dan partisipasi secara aktif dalam pembangunan bidang sosial atau keagamaan dengan menggunakan bahasa atau ajaran agama.

Berdasarkan rumusan pengertian tentang penyuluhan tersebut di atas, maka dapat dimaknai bahwa penyuluhan salah satunya merupakan proses pengubahan perilaku dengan pendekatan komunikasi. Keniscayaan bahwa penyuluh agama menguasai tentang komunikasi baik secara teori maupun secarapra ktiknya.

Penyuluh Agama yang dimaksud adalah PNS yang diberitugas, tanggungjawab, wewenang dan hak secara penuh oleh pejabat yang berwenang untuk melakukan bimbingan/ penyuluhan agama, dan pengembangan bimbingan/penyuluhan agama dan pembangunan.

TantanganPenyuluh Agama 
Dalam teori globalisasi menuntut manusia membuat perubahan secara cepat. Pada saat pendemi covid 19 seperti sekarang ini, teori ini terbukti dengan adanya pergeseran perilaku masyarakat.
2. Berkembanganya wacana Islam yang fundamental dan radikal di satu sisi serta Islam liberal disisi yang lain.

3. Tantangan dalam mengatasi

\begin{tabular}{|c|c|c|}
\hline $\begin{array}{l}\text { Masyarakat } \\
\text { Umum }\end{array}$ & $\begin{array}{c}\text { Masyarakat } \\
\text { Perkotaan }\end{array}$ & Masyarakat Khusus \\
\hline $\begin{array}{l}\text { - Masyarakat } \\
\text { pedesaan } \\
\text { - Masyarakat } \\
\text { transmigra } \\
\text { si }\end{array}$ & $\begin{array}{l}\text { - Komplek } \\
\text { perumahan } \\
\text { - Real estate } \\
\text { - Asrama } \\
\text { - Daerah } \\
\text { Pemukiman } \\
\text { baru } \\
\text { - Masyarakat } \\
\text { pasar } \\
\text { - Masyarakat } \\
\text { daerah rawan } \\
\text { - Karyawan } \\
\text { instansi } \\
\text { pemerintah } \\
\text { - Masyarakat } \\
\text { industry dan } \\
\text { sekitar kawasan } \\
\text { industri }\end{array}$ & $\begin{array}{l}\text { - Cendikiawan (pegawai negeri, } \\
\text { professional, akademisi) } \\
\text { - Genersi muda (remaja, } \\
\text { karang taruna, pramuka) } \\
\text { - Lembaga pendidikan } \\
\text { masyarakat (majelis taklin, } \\
\text { pondok pesantren, TPA/TPQ, } \\
\text { persatuan kaum wanita) } \\
\text { - Binaan khusus (pantir } \\
\text { ehabilitasi/pondok sosial, } \\
\text { rumah sakit, masyarakat } \\
\text { gelandangan dan pengemis, } \\
\text { kelompok masyarakat } \\
\text { khusus/lokalisasi, lembaga } \\
\text { permasyarakatan, calon } \\
\text { Jemaah haji dan pasca haji), } \\
\text { daerah terpencil (masyarakat } \\
\text { daerah terpencil, masyarakat } \\
\text { suku terasing). }\end{array}$ \\
\hline
\end{tabular}

Tabel.1. Sasaran/Wilayah Kerja Penyuluh Agama

Perubahan ini tanpa disadari telah membentuk aktivitas baru semenjak berlakunya kebijakan pemerintah yaitu adaptasi kebiasaan baru / New Normal, terkait bekerja dari rumah, belajar dari rumah dan beribadah dari rumah.

Tantangan bagi penyuluh agama di era digital diantaranya :

1. Perubahan perilaku masyarakat akibat perkembangan ilmu pengetahuan dan teknologi. problem moralitas dan karakter bangsa Indonesia yang kian merosot danmelemah.

Sasaran / wilayah kerjapenyuluh agama terbagi menjadi tiga yaitu masyarakat umum, masyarakat perkotaan dan masyarakat khusus. Wilayah sasaran kerja yang begitu luas, sedangkan jumlah rasio idealnya ketersediaan penyuluh satu kecamatan 1 orang penyuluh. Untuk mengatasi 
masalah ini maka seorang penyuluh agama wajib menguasai kompetensi dasar dan kompetensi subtansi. Kompetensi dasar salah satunya yaitu kemampuan komunikasi baik lisan maupun tulisan.

\section{TentangKomunikasi}

Komunikasi secara umum menurut Lucie (2005) adalah suatu pernyataan antar-manusia, baik secara perorangan maupun berkelompok yang bersifat umum dengan menggunakan lambang-lambang tertentu yang berarti. Sementara menurut Berlo (Mardikanto, 1991) komunikasi diartikan sangat sederhana, yaitu "suatu proses penyampaian pesan dari sumber ke penerima".

Sebenarnya pada kenyataan hidup manusia, proses komunikasi tidak hanya terhenti setelah pesan disampaikan atau diterima oleh penerima, tetapi dimana penerima memberikan tanggapannya kepada sumber/pengirim pesan untuk kemudian proses komunikasi tersebut terus berlangsung, dimana pengirim dan penerima pesan saling berganti pesan. Proses komunikasi tersebut akan/baru berhenti jika penerima telah memberikan tanggapan yang dapat dimengerti oleh pengirimnya, baik tanggapan tersebut sesuai atau tidak sesuai dengan yang dikehendaki oleh pengirimnya. Oleh karen hal tersebut di atas maka Scramm (Mardikanto, 1991) merumuskan arti dari komunikasi, yaitu: "proses penggunaan pesan oleh dua atau lebih, dimana semua fihak saling berganti peran sebagai pengirim dan penerima pesan, sampai ada saling pemakhaman atas pesan yang disampaikan oleh semua fihak". Dari penjelasan tersebut di atas dapat dikatakan prinsip proses komunikasi tersebut bersifat mengalir.

Tetapi Zulkarimein (1989) juga mengatakan bahwa komunikasi merupakan suatu proses transaksonal dan simbolik, yang memungkinkan orang untuk berhubungan dan mengelolanya melaui: (a) penegakan kontak antar orang, (b) tukar menukar informasi, (c) memantapkan (to reinforce) sikap dan perilaku orang lain, (d) mengubah sikap dan perilaku orang lain. Sifat transaksional dari proses komunikasi berarti bahwa semua orang ikut mempengaruhi dan dipengaruhi oleh komunikasi, dan juga hubungan mereka dalam interaksi tersebut. Jadi pada prinsipnya, kedua belah pihak (komunikator dankomunikan) akan mengalami perubahan, hanya berbeda dalam kadar derajatnya.

Komunikasi secara paradigmatis adalah proses penyampaian pesan oleh seseorang kepada orang lain untuk memberi tahu atau untuk mengubah sikap, pendapat atau perilaku, baik langsung maupun tidak langsung melalui saluran atau media. Definisi tersebut jelas terkandung maksud atau tujuan tertentu yang diharapkan dari adanya proses komunikasi tersebut, yakni memberi tahu atau sampai dengan mengubah sikap (attitude), pendapat (opinion), atau perilaku (behavior). Menurut Soekartawi (1991) ada 
perbedaan dalam memahami istilah komunikasi dan penyuluhan, komunikasi adalah suatu pernyataan antar-manusia yang berkaitan dengan kegiatan tertentu, baik secara perorangan maupun kelompok yang sifatnya umum dengan menggunakan lambang tertentu. Adapun penyuluhan adalah sistem pendidikan non-formal bagi kelompok sasaran dan keluarganya dengan tujuan agar mereka mau dan mampu untuk memperbaiki atau meningkatkan taraf hidup dan kesejahteraannya. Kedua pengertian di atas nampak ada perbedaan yang cukup mendasar.

Berdasarkan hal tersebut di atas, menunjukkan komunikasi tidak lagi bersifat garis lurus "linier" tetapi bersifat memusat atau "convergence" , dimana pesan itu disampaikan secara bergantian baik oleh pengirim maupun penerima, sampai pesan tersebut mendapat tanggapan. Implementasinya, komunikasi yang berlangsung dalam berbagai bentuk kegiatan tentu mempunyai tujuan yang berbeda-beda dan selalu mempunyai kejelasan, sekalipun pada akhirnya tujuan tersebut dapat dilaksanakan secara bersamaan. Menurut Mardikanto (1991) di dalam setiap komunikasi sedikitnya akan terkandung salah satu dari tiga (3) macam tujuan komunikasi, yaitu: (a) untuk memberikan informasi/berita (informatif), (b) untuk membujuk (persuasive), dan (c) untuk memberikan hiburan (intertainment). Jadi sangat jelas sekali setiap model komunikasi memiliki tujuan yang berbeda-beda, akan tetapi pelaksanaan proses komunikasi tersebut dapat memiliki lebih dari satu tujuan, yang penting ada kejelasan tujuan utamanya.

Disamping ada kejelasan tujuan dalam komunikasi, juga hal yang penting adalah adanya unsur-unsur dalam komunikasi, yang terdiri dari (a) usur pesan yang disampaikan, dapat berupa informasi, berita, gagasan, cita-cita atau harapan, atau dalam bentuk ide-ide baru yang dikenal dengan istilah inovasi, (b) unsur saluran/media/chanel yang dipakai, (c) unsur komunikator/pengirim yang trampil secara lisan, tulisan, maupun peragaan, dan (d) komunikan/penerima, juga trampil seperti komunikator. Terkait dengan unsur komunikasi tentang pesan, dalam komunikasi pembangunan tentu mempunya makna yang lebih luas mencakup banyak aspek, baik ekonomi, sosial, budaya, kesehatan, pendidikan politik dan sebagainya. Hal tersebut tentu menyangkut pesan-pesan pembangunan yang dapat disampaikan melalui kegiatan penyuluhan, dimana pesan tersebut haruslah mampu mendorong atau mengakibatkan terjadinya perubahan-perubahan yang memiliki sifat "pembaharuan" yang biasa disebut dengan istilah "inovativeness".

Rogers dan Shoemaker (Mardikanto, 1991) mengartikan inovasi atau pesan dalam komunikasi adalah sebagai ide-ide baru, praktek-praktek baru, atau obyek-obyek yang dapat dirasakan sebagai sesuatu yang baru oleh penerima pesan tersebut. Sementara Lionberger dan Gwin (1991) mengartikan 
tidak sekedar sebagai sesuatu yang baru, akan tetapi lebih luas dari itu, yakni sesuatu nilai baru atau dapat mendorong terjadinya pembaharuan dalam masyarakat atau pada lokalitas tertentu. "Baru" disini mengandung makna bukan sekedar "baru diketahui" oleh pikiran, akan tetapi juga karena belum dapat diterima secara luas oleh seluruh warga masyarakat secara sikap, dan juga baru dalam pengertian belum diterima dan dilaksanakan/diterapkan oleh seluruh warga masyarakat tersebut. Intinya tentang inovasi (sesuatu hal yang baru), bukan selalu berarti baru diciptakan, tetapi dapat berupa sesuatu yang sudah "lama" dikenal, diterima, atau digunakan/ditrapkan oleh masyarakat di luar sistem sosial yang menganggapnya sebagai sesuatu yang masih baru.

\section{Peyuluhan Sebagai Proses Komunikasi}

Penyuluhan pada hakekatnya adalah suatu kegiatan komunikasi. Proses yang dialami mereka yang disuluh/kelompok sasaran sejak mengetahui, memahami, meminati, dan kemudian menerapkannya dalam kehidupan yang nyata, adalah suatu proses komunikasi. Dengan demikian kelihatanlah bagaimana pentingnya memenuhi persyaratan komunikasi yang baik untuk tercapainya hasil penyuluhan yang baik. Suatu komunikasi baru berhasil bila kedua belah fihak samasama siap untuk itu, demikian juga dengan penyuluhan; dimana kegiatan penyuluhan menuntut suatu persiapan, penyuluhan perlu suatu perencanaan yang matang, dan bukan dilakukan secara asal-asalan saja. Persiapan dan perencanaan inilah yang hendak dipenuhi dengan menyusun terlebih dahulu suatu disain komunikasi penyuluhan.

Melihat bentuk dan tujuannya, penyuluhan merupakan wujud konkrit dari apa yang sekarang dikenal dengan sebutan komunikasi pembangunan. Dalam arti yang luas, komunikasi pembangunan meliputi peran dan fungsi komunikasi (sebagai suatu aktivitas pertukaran pesan secara timbal balik) antara semua fihak yang terlibat dalam usaha pembangunan; terutama antara pemerintah dan masyarakat, sejak dari perencanaan, kemudian pelaksanaan, dan penilaian terhadap hasil pencapaian pembangunan. Sedangkan dalam arti sempit, menurut Zulkarimein (1989) komunikasi pembangunan merupakan segala upaya dan cara, serta teknik penyampaian gagasan, dan ketrampilanketrampilan yang ditujukan kepada masyarakat luas. Kegiatan tersebut bertujuan agar masyarakat/klompok sasaran dapat memahami, menerima dan berpartisipasi dalam melaksanakan gagasan-gagasan yang disampaikan tersebut. Berdasarkan pemahaman tersebut di atas terkait dengan kegiatan penyuluhan juga perlu dipersiapkan secara terperinci dan spesifik. Menurut Zulkarimein (1989) penyuluhan harus menggambarkan pokok-pokok atau unsur komunikasi, seperti hal-hal: (a) masalah yang dihadapi, (b) siapa yang akan disuluh, (c) apa tujuan yang hendak dicapai dari setiap kegiatan penyuluhan, 
(d) pendekatan yang digunakan, (e) pesan yang dikembangkan, (f) metode, teknik dan media yang digunakannya, (g) sistem evaluasi terhadap hasil kegiatan penyuluhan.

Seperti yang disampaikan Scramm di atas (1991) tentang komunikasi yang bersifat "convergence" tersebut, di dalam kegiatan penyuluhan pun, proses komunikasi antara penyuluh dengan kelompok sasarannya juga tidak hanya terhenti jika penyuluh telah menyampaikan inovasi/pesan yang disampaikan penyuluh, akan tetapi sering kali komunikasi baru berhenti jika kelompok sasaran telah memberikan tanggapan seperti yang dikehendaki oleh penyuluh, yaitu berupa penerimaan dan penerapan inovasi/pesan tersebut; baik yang ditunjukan pada perubahan pengetahuan, pemahaman, kemauan, bahkan ketrampilannya.

Hubungannya dengan macam tujuan dalam komunikasi, baik untuk memberikan informasi, membujuk dan memberikan hiburan; komunikasi yang berlangsung selama proses penyuluhan selalu mengandung ketiga macam tujuan tersebut, meskipun dengan kadar yang tidak selalu sama. hal Tersebut disebabkan karena tujuan utama penyuluhan adalah mendidik. Artinya mempengaruhi orang lain agar mau menerima/ melaksanakan informasi yang disampaikannya dengan senang hati. Meskipun demikian, bobot "hiburan" harus dijaga untuk tidak terlalu dominan, agar informasi yang diberikan dapat diampaikan dengan porsi yang lebih besar, sehingga memungkinkan

sasarannya memperolehnya cukup lengkap dan jelas.

Terkait dengan pemikiran tentang komunikasi secara paradigmatis, komunikasi dalam penyuluhan lebih tepat dimasukkan dalam kelompok definisi komunikasi paradigmatis, karena pada proses komunikasi dalam penyuluhan selalu dikaitkan dengan tujuan untuk mengubah sikap, pendapat atau perilaku, pengetahuan dan ketrampilan dari kelompok sasaran komunikasi, baik secara langsung atau tidak, sehingga sasaran komunikasi akan berubah menuju ke arah lebih baik dengan cara mengikuti saran, gagasan atau inovasi yang disampaikan. Menurut Jones (1991) proses komunikasi dalam penyuluhan sangat kompleks, karena banyak faktor yang terlibat di dalamnya. Proses komunikasi dalam penyuluhan tidak semata-mata berpindahnya pesan dari penyuluh/komunikator kepada kelompok sasaran atau komunikan, tetapi bagaimana pesan tersebut dapat diterima, dimengerti oleh kelompok sasaran sehingga timbul suatu kesadaran, yang berlanjut ke minat, keinginan untuk menimbang-nimbang, dan mencoba hingga menerapkan pesan yang disampaikan oleh penyuluh/komunikator dengan kesadarannya sendiri. Karena tujuan yang hendak dicapai dari suatu proses komunikasi sedemikian kompleksnya, maka diperlukan upaya komunikasi yang terstruktur, dan terus menerus atau berkelanjutan.

Kegiatan penyuluhan tidak lepas dari beberapa komponen penting yang 
tidak boleh dihindarkan, yaitu proses komunikasi, tentang inovasi atau sesuatu hal yang baru yang akan disampaikan, proses adopsi inovasi, dan difusi inovasi.

Menurut Soekandar (1978) proses komunikasi yang terjadi dalam penyuluhan ada lima (5) tahapan, yaitu:

a. Tahap menarik perhatian, yaitu inovasi yang disampaikan menimbulkan perhatian dari kelompok sasaran. Hal ini biasa dipakai media penyuluhan masal, seperti: poster, spanduk, brosur, stiker, pameran, film, dan lain sebagainya.

b. Tahap menggugah hati, yaitu menimbulkan perasaan terbuka pada kelompok sasaran akan inovasi yang menarik tersebut. Ada kemauan untuk mengetahui lebih banyak lagi tentang inovasi tersebut. Media penyuluhan yang dipakai tidak berbeda dengan tahap sebelumnya

c. Tahap membangkitkan keinginan, yaitu menumbuhkan keinginan untuk memperoleh atau menggunakan/menerapkan inovasi tersebut. Media penyuluhan yang dipakai tidak berbeda dengan tahap sebelumnya, dilengkapi dengan konsultasi, kunjungan rumah, dan lain sebagainya.

d. Tahap meyakinkan, yaitu menghilangkan perasaan ragu-ragu pada kelompoksasaran, sehingga terjadi keyakinan akan kebermanfaatan/bergunanya inovasi tersebut. Caranya dengan percobaan atau demonstrasi. e. Tahap menggerakan atau menerapkan, yaitu mengusahakan agar inovasi tersebut oleh kelompok sasaran diterima untuk ditrapkan/digunakan/dipraktekan/ atau dilaksanakan, secara luas dan kontinu. Pada tahap ini penyuluh tidak melepaskan begitu saja, tetapi kelompok sasaran selalu dalam bimbingan penyuluh sampai dinilai sudah mampu mandiri.

Berbicara tentang adopsi, menurut Mardikanto (1991) adalah proses perubahan perilaku pada kelompok sasaran setelah menerima inovasi yang disampaikan oleh penyuluh. Hal tersebut tidak berbeda jauh dari pendapat Soekandar (1978) bawa adopsi merupakan suatu proses mental yang tidak dapat dilihat, hanya dapat dimaklumi dari tingkah-laku kelompok sasaran, proses tersebut tidak sekonyong-konyong, akan tetapi memerlukan waktu sampai dengan kelompok sasaran membuat keputuan untuk menerima inovasi tersebut. Proses penerimaan inovasi atau proses adopsi ini menurut Mardikanto (1991) ada lima

(5) tahapan, yaitu:

a. Tahap awarenessatau kesadaran, yaitu sasaran mulai sadar tentang adanya inovasi yang ditawarkan oleh penyuluh.

b. Tahap interest atau minat, yaitu sasaran mulai tumbuh minat akan inovasi tersebut, yang seringkali ditandai oleh keinginannya untuk bertanya atau keinginan mengetahui lebih banyak/lebih jauh/mendalam tentang inovasi tersebut. 
c. Tahap evaluation atau penilaian, yaitu penilaian terhadap baik/buruknya atau bermanfaat/tidaknya inovasi yang telah diketahui secara lebih lengkap. Penilaian ini tidak saja bersifat teknis saja, tetapi pada aspek ekonomi, sosial-budaya, bahkan sering kali juga dari aspek politis.

d. Tahap trial atau mencoba, yaitu mencoba dalam skala kecil untuk meyakinkan penilaiannya, sebelum menerapkan dalam jumlah yang lebih besar dan luas. Pada tahap ini kelompok sasaran akan menilai dan meyakini untuk cepat mengambil keputusan.

e. Tahap adoption atau menerima/menerapkan, yaitu dengan penuh keyakinan berdasarkan penilaian dan uji coba tentang inovasi yang telah dilakukan dan diamatinya sendiri, sehingga sasaran mengambil keputusan untuk menerima inovasi tersebut.

Menurut Mardikanto (1991) Cepat atau lambatnya proses adopsi atau proses pengambilan keputusan menerima inovasi tersebut tentu tidak lepas dari faktor yang mempengaruhinya, seperti a) faktor pribadi dan lingkungan dari kelompok sasaran, b) sifat dari inovasinya, c) sifat dari sasarannya, d) cara pengambilan keputusan, e) saluran komunikasi yang digunakan, f) keadaan penyuluh, dan g) ragam sumber iformasi.Cepat dan lambatnya proses adopsi tersebut dapat digambarkan dalam golongannya, yaitu: a) Golongan pelopor atau innovator, b) Golongan pengetrap dini atau early adopter, c) Golongan pengetrap awal atau early majority, d) Golongan pengetrap akhir atau late majority, e) Golongan penolak atau laggard.

Satu lagi komponen yang tidak kalah pentingnya dalam proses penyuluhan, yaitu difusi inovasi. Difusi inovasi adalah proses perembesan adopsi inovasi dari satu individu yang telah mengadopsi ke individu yang lain dalam sistem sosial masyarakat kelompok sasaran yang sama. Berlangsungnya proses tersebut tidak berbeda dengan proses adopsi inovasi. Bedanya adalah, jika dalam proses adopsi pembawa inovasinya berasal dari "luar" sistem sosial masyarakat sasaran, sedangkan dalam proses difusi, sumber informasinya berasal dari daam sistem sosial masyarakat sasaran itu sendiri.

Tentang cepat atau lambatnya proses difusi juga tergantung kepada aktivitastang dilakukan oleh penyuluhnya sendiri. Beberapa usaha yang dilakukan penyuluh agar mempercepat proses difusi menurut Lucie (2005) adalah sebagai berikut:

a. Melakukan diagnosis atau assesmen terhadap masalah/isu-isu dan kebutuhan yang dirasakan masayarakat.

b. Mengkondisikan masyarakat sasaran agar tidak puas terhadap kondisi saat sekarang.

c. Menjalin hubungan dan kerjasama yang erat dengan masyarakat sasaran. 
d. Mendukung dan membantu masyarakat sasaran melakukan perubahan.

e. Mendorong masyarakat berswakarya dan berswadaya melakukan perubahan tanpa tergantung bantuan dari luar sistem sosialnya.

Berdasarkan penjelasan di atas secara keseluruhan tentang penyuluhan sebagai proses komunikasi, maka dapatlah disimpulkan bahwa komunikasi baik yang sifatnya linier, covergence, dua arah atau two way traffic communication, bersifat transactional, atau komunikasi paradigmatis, itu semua terjadi dalam pelaksanaan kegiatan penyuluhan. Komponen penting dalam penyluhan merupakan bagian penting juga dalam proses komunikasi; seperti dalam proses adopsi inovasi tentu dilakukan dengan proses komunikasi yang terstruktur, begitu juga proses difusi inovasi dari individu satu ke individu lainya terjadi melalui proses lomuniksi yang terstruktur. Berdasarkan uraian tersebut di atas maka dapat disimpulkan bahwa penyuluhan merupakan suatu proses kegiatan komunikasi yang dirancang secara konstruktif dan dilakukan berkesinambungan.

\section{Peluang Penyuluh Agama}

Selain tantangan ada juga peluang. Sebenarnya ini merupakan hal yang sama, tergantung cara pandang dan pola pikIr seseorang dengan hal tersebut. Dengan adanya tantangan sekaligus menjadi peluang bagi penyuluh agama untuk menjadi yang terbaik/ atau target penyuluhan tercapai dengan baik.

Adapunpeluanganpenyuluh agama dera digital yaitu :

1. Kemajuan teknologi :membuat sesorang bias mengakses informasi dengan mudah kapan saja dan dimana saja. Ini merupakan kemudahan bagi penyuluh agama dalam memberikan pemahaman dan penyuluhan/bimbingan kepada masyarakat secara luas.

2. Jumlah penduduk Indonesia yang mencapai 270.203.917 jiwa (data Badan Pusat Statistik tahun 2020). Menjadikan Indnesia sebagai Negara berpenduduk terbesar keempat di dunia. Negara berpenduduk muslim terbesar di duniaya itu mencapai 230 juta orang. Ini menjadi kelompok sasaran kerja penyuluh agama yang menjadi asset dunia- akhirat.

Perubahan perilaku dan gaya hidup masyarakat yang kian berkembang dan tidak mengenal tempat serta waktu menyebabkan digitalisasi mudah diterima masyarakat dunia. Kemudahan akses internet terbukti memudahkan masyarakat melakukan apapun, di manapun dan kapanpun. Termasuk penyuluhan agama. Saat ini kebutuhan masyarakat kebanyakan bukan hanya soal sandang, pangan dan papan saja tapi juga dukungan perangkat digital. 


\section{DaftarPustaka}

Arief Subhan, 2017 Penyuluh Agama Dalam Konteks; Menatap Masa depan Dalam Masyarakat yang Berubah, Suluh Vol. IV, No.1, 2017

Lucie Setiana. 2005. Penyuluhan dan pemberdayaan masyarkat. Bogor: Ghalia Indonesia.

M. TaufikHidayatullah, 2014 Kualifikasi dan Kompetensi Penyuluh Agama Islam Profesional, Jurnal Dakwah Voll. XVIII, No. 2

Mardikanto. 1991. Penyuluhan pembangunan pertanian. Surakarta: Sebelas Maret University Press.

Pusat Penyuluhan Sosial. 2008. Peraturan Bersama Menteri Sosial dan Kepala Badan Kepegawain Negara, No. 41/HUK-PPS/2008 dan No. 13 Tahun 2008, Tentang Petunjuk Pelaksanaan Jabatan Fungsional Penyuluh Sosial dan Angka Kriditnya. Jakarta: Departemen Sosial

Rogers Everen. 1976. Komunikasi dan pembangunan. Jakarta: LP3ES.

Roling Niels. 1988. Extention science. New York: Cambridge University Press.

Samsudin. 1976. Dasar-dasar penyuluhan dan modernisasi pertanian. Bandung: Binacipta.

Soekandar W. 1978. Pokok-pokok penyuluhan pertanian. Jakarta: CV. Yasaguna.

Suhardiyono. 1990. Penyuluhan, petunjuk bagi penyuluh pertanian. Jakarta: Erlangga.
Zulkarimein Nasution. 1989. Prinsipprinsip komunikasi untuk penyuluhan. Jakarta: Lembaga Penerbit, Fakultas Ekonomi Universitas Indonesia.

Abdul Rahman adalah dosen pada Fakultas Ilmu Dakwah dan Ilmu Komunikasi Universitas Islam Negeri Syarif Hidayatullah Jakarta. 